\title{
MARKETING LOGISTICS MANAGEMENT IN E-RETAIL - THE ESSENCE AND SELECTED PRACTICAL ASPECTS
}

\author{
JOANNA DROBIAZGIEWICZ \\ University of Szczecin, Faculty of Management and Economics of Services, POLAND \\ e-mail: joanna.drobiazgiewicz@wzieu.pl
}

\author{
\begin{tabular}{l|l} 
RECEIVED & 18 January 2018
\end{tabular} \\ \begin{tabular}{l|l} 
ACCEPTED & 2 September 2018
\end{tabular} \\ JEL \\ CLASSIFICATION \\ D30, M30
}

KEYWORDS marketing, logistics, e-retail, 4C

ABSTRACT $\quad$ The growing demands of consumers evoke the need for enterprises to undertake many innovative activities aimed at the greatest possible satisfaction of the client with the assumption of optimizing the costs of these activities. One of the modern methods of managing both the enterprise itself and the entire supply chain is the marketing logistics management concept. Marketing logistics management is a kind of expression of the coupling and integration of two concepts: logistics as a concept of flow-oriented management and marketing as a market-oriented concept of business management. The objective of the article is to present the concept of marketing logistics management and to point out its selected practical aspects in the area of e-retail. At the beginning of the article the concept of marketing logistics management was clarified and then its e-retail characteristics were described. In this part reference is made to the $4 \mathrm{C}$ concept in relation to marketing activities and the impact of this concept on the area of logistics activities was pointed out. The next part of the article describes a practical example of implementing activities, which integrate the area of marketing and logistics in a trading company. The conclusions were formulated at the final part of the article. The paper uses the methods of literature review, case study analysis and synthesis.

\section{Introduction}

Initially, marketing and logistics were treated in enterprises as separate areas. The reasons for this approach were the perception of the role of logistics only in the aspect of transport and storage processes. The narrow field of view also applied to marketing management, which focused only on the areas of product strategy, promotion and price. Conscious distribution management, also including logistics, has been a rarity. 
The-evolution of both concepts allowed us to see that effective logistics is a key part of the marketing strategy that enables us to achieve a competitive advantage. Both marketing and logistics adjust processes to the needs and expectations of customers. They complement each other, because marketing stimulates demand for products or services and logistic activities allow for their proper distribution (Blaik, 2010, p. 300).

\section{Concept of marketing logistics management - literature overview}

Literature describes various definitions and relations between marketing and logistic. Sometimes marketing and logistics are treated as separate spheres, sometimes one of them is superior to the other, they are also described as equivalent concepts or as systemically integrated areas (Pokusa, 2007, pp. 41-59; Worobjow, 2010, pp. 243-252). The following megatrends can be observed in the environment, which have a significant impact on both marketing and logistics (Bujak, 2014, pp.133-151; Kaźmierczak, 2016, pp. 95-108):

- in-crease in customer requirements,

- growing competition, changes in the information technologies and telecommunications,

- shorter life cycles of products,

- development of modern distribution channels for goods,

- corporate social responsibility - CSR,

- efficiency and flexibility of the company.

Recognizing these changes in the environment, it seems reasonable to look at the concept of logistics and marketing as elements that together participate in creating a value chain for the customer.

In accordance with the concept of value chain management, enterprises should focus on providing the client with appropriate, maximum in given organizational conditions, values in a given area and constantly improve it, while maintaining the right level in other areas. This guarantees achieving a steady increase in customer satisfaction, and thus a long-term competitive advantage. The marketing and logistic processes have a significant contribution to the creation of the expected value by the customer. Marketing processes such as developing the product idea or building long-term relationships and communication with the client are of particular importance. On the other hand, the most important logistics processes are flow coordination processes, ensuring timeliness and convenience of deliveries, optimizing stock levels, organizing transport and ensuring a high level customer service (Pokusa, 2006, pp. 51-62).

Logistics value chain is one part of the enterprise's value chain, which includes such external logistics activities as delivery of raw materials and finished goods, and also involves such internal logistics activities as production and selling. In the traditional structure of value chain, the "logistics" activities were shown in internal logistics and external logistics, but all of them are parts of logistics value chain (Zhou, Zhang, 2010, pp. 26-29).

A prerequisite for the implementation of all dimensions of values for the client is to develop an appropriate concept and principles for shaping the logistics and marketing chain of creating and delivering value (Pokusa, 2006, pp. 51-62).

The integration of logistics and marketing functions is a process of interaction and cooperation, the aim of which is to obtain mutually acceptable results for the company (Topolsek, Borut, Cvahte, 2016, pp. 29-32).

The basic features of logistic and marketing management are presented in Table 1. 
Table 1. Characteristics of of marketing logistics management

\begin{tabular}{ll}
\hline \multicolumn{1}{c}{ Basic reference areas } & \multicolumn{1}{c}{ Properties and dimensions of marketing logistics management } \\
\hline $\begin{array}{ll}\text { Integration } & \text { Integration of logistic and marketing in the scale of enterprise and market management } \\
\text { System } & \text { Logistic and marketing management functions as a business management subsystem } \\
\text { Management concept } & \text { The flow and market oriented concept of integrated enterprise management } \\
\text { Processes } & \text { logistic and marketing management as a chain of key management and transformation processes in the enterprise } \\
\text { Management instruments } & \begin{array}{l}\text { Logistics management as a subsystem of management tools (strategic and operational aspects of logistics - mix and } \\
\text { marketing mix) } \\
\text { Efficiency }\end{array} \\
& \text { Logistics and marketing management as a system orientation and determinant of effectiveness (gaining an advantage } \\
& \text { in terms of efficiency in business management and on the market) }\end{array}$ \\
\hline
\end{tabular}

Source: own elaboration based on Blaik (2007), p. 46.

The marketing and logistic activities implemented create a coherent system allowing to achieve optimization in the areas of: customer service, transport, inventory control, storage, location of production plants and warehouses, order fulfillment, material supply, demand forecasting, information management, material flows, service after-sales service and handling returns and complaints.

Competing for a buyer only by offering the right product quality is no longer enough, because logistic service plays an extremely important role.

Harrison and Hoek point out four basic determinants of customer orientation in Logistics (Harrison, Hoek, 2010, pp. 67-96):

- marketing perspective,

- market segmentation,

- service quality,

- logistic strategies subordinated to the interests of clients.

The concept of logistic and marketing management uses marketing mix and logistics-mix instruments (Blaik, 2010, pp. 302-304). Today, in relation to marketing, the formula 4C is used, which includes (Wang, Wang, Yao, 2005, pp. 660-669):

- customer need and wants,

- cost to the customer,

- communication,

- convenience.

In terms of logistics, we can identify the following components (Fernie, Sparks, 2004, pp. 1-25; Blaik, 2010, pp. 302-304; Llamazares, 2015, p. 186):

a) storage facilities (What types and how many warehouses should be provided and where they should be located?);

b) inventory (How many stocks should you keep in your country or region? Where exactly are they to be stored? What technology should be used in the storage and picking processes?);

c) transportation (Own transport or outsourcing services? How often should you provide? What should the delivery schedule be?);

d) unitization and packaging (The consolidation of a quantity of cargo into one large shipping unit for easier handling, as in palletizing or containerization; 
e) communications (flow of information - for example: invoicing, demand forecasting, sales reporting issues);

f) order fulfillment and service process (receiving and handling orders, after sales service).

\section{Adaptation of marketing logistics mannagement concept tor e-petail needs}

Online market creates enormous opportunities for business development in the future. Using the Internet as an additional sales channel is now becoming a necessary condition for the company's competitiveness. In addition, due to the increasing cost pressure, special attention should be paid to process optimization. A special process is the handling of orders, which perceived as an added value to a basic product may be a determining factor in the selection of a supplier. To ensure the optimization of e-retail processes, a concept integrating marketing and logistics activities is introduced. Table 2 presents the characteristics of the $4 \mathrm{C}$ concept for e-retail's needs.

Tahle 2. 4C concept for e-retail

\section{C components}

\begin{tabular}{|c|c|}
\hline $\begin{array}{l}\text { Customer need and } \\
\text { wants }\end{array}$ & $\begin{array}{l}\text { Both retailers and e-retailers should offer products and appropriate customer service that will satisfy customers' } \\
\text { expectations to the maximum extent. The basic task of retail and e-commerce is to choose a range of products offered } \\
\text { for sale and coming from various sources. A wide and deep assortment that You can offer is a characteristic feature } \\
\text { of e-retail. The possibility of individualizing the product. } \\
\text { Buyers of products online have less opportunities to get advice on the choice of the purchased product, in case } \\
\text { of indecision choose other purchase channels. } \\
\text { In order to convince the customer to make a proper purchase, e-retailers should accurately describe the products sold in } \\
\text { order to clearly present value and benefits terms }\end{array}$ \\
\hline Cost to the customer & $\begin{array}{l}\text { It should be noted that the costs of purchasing goods online also include transport costs and Internet access costs. When } \\
\text { the transport costs are too high, the customer will resign from the purchase. } \\
\text { E-retailers to encourage buyers to buy can lower the price of products only in the online channel or offer products that are } \\
\text { not available through other channels. } \\
\text { Supplier and price comparisons can be done easily and quickly, which can also increase the cost savings as well. } \\
\text { The possibility of individualizing the prices }\end{array}$ \\
\hline Communication & $\begin{array}{l}\text { Communication is a two-way process also involving feedback from customers to suppliers. } \\
\text { Communication is not just advertising but all the ways in which retailers communicate with their customers, including, for } \\
\text { example, marketing research public relations (PR), social media, direct mail, e-mail and loyalty programs. } \\
\text { The task of e-retailers is to provide the possible exact characteristics of the product (s) being sold, which in the case } \\
\text { of sales in the traditional store is easier, because you can see the product live, touch it and see how it works }\end{array}$ \\
\hline Convenience & $\begin{array}{l}\text { Many customers prefer a multi-channel approach: browse on the web, buy instore or vice versa - or buy on the web, return } \\
\text { to the physical store for a refund. } \\
\text { Physical store can also be important for the e-retailer becouse many customers prefer to buy from your own country due } \\
\text { to more more confidence in in the seller and lower transport costs. } \\
\text { Virtual location and the ease of finding the website. } \\
\text { Website design such as navigation, layout and ease of purchase. } \\
\text { The customer spends less time to buy the product. } \\
\text { The opportunity to purchase a product or service in electronic form. } \\
\text { The need to ensure security on the Web }\end{array}$ \\
\hline
\end{tabular}

Source: own elaboration based on Dennis, Merrilees, Fenech (2005), pp. 179-193; Wang, Wang, Yao (2005), pp. 660-669.

The introduction of the $4 \mathrm{C}$ concept in $\mathrm{B} 2 \mathrm{C}$ e-commerce has a significant impact on the shaping of logistics processes, whose main task is to ensure coordination of activities and optimization of goods and information flows.

The logistical consequences of the $4 \mathrm{C}$ concept in e-retail are as follows (Lasgaa, 2010, pp. 1-18; Dennis, Merrilees, Fenech, 2005, pp. 179-193): 
- the possibility for e-shopping is becoming available for more customers from different places in the country and from abroad increases the logistics service area,

- making purchases via the internet causes that the intermediary, especially wholesalers, in the supply chain can be deleted which make the product cheaper than buying it in a traditional store,

- supplying the products that customers want, in the right sizes and quantities, at the right time and in the right place; convenience for the consumer means the possibility of choosing a place of delivery such as a stationary store, kiosk, fuel station, etc.,

- thanks to the use of modern IT systems the supplier can react immediately on potential needs of the customer,

- smaller order sizes but larger number of buyers,

- customers orders are much more unpredictable and unstable,

- management of a larger product assortment than in traditional off-line stores,

- inventory management and shipment is based on supply chain connectivity and visibility,

- combining of fresh products with and non-food products in one electronic order asks mostly additional activities like consolidation, co-packing and cross docking,

- larger returns-flows to the supplier than in traditional trade,

- demand for on-line shipment tracking information,

- bigger focus on personalized marketing, which creates demand for customized delivery and after-sales customer services,

- need for introduction efficient supply chains with computer network links between suppliers and retailers,

- co-operation between suppliers and retailers has been key to improving the efficiency of satisfying customers whilst minimising stocks and costs. Stock levels have been reduced using techniques such as Electronic Point-of-Sale, Quick Response and Efficient Customer Response.

\section{Integration of logistics and marketing activities - case study}

"Smyk" is an international chain of specialist stores with articles for children. The company's mission is to offer everything that children need and dream about. The philosophy of "Smyk" chain stores is (Smyk, 2018):

- the widest selection of products for children from the moment of birth to the age of 14 ,

- the highest quality of products,

- attractive prices,

- professional service and specialist consulting,

- a number of attractions and educational activities for children.

"Smyk" chain stores are located in the largest Polish cities. Since 2006, the company has entered foreign markets and is constantly growing. In 2011, the company began selling online via smyk.com. In 2015, the "multichannel retail" strategy was implemented, including the tight integration of an online store with a chain of all stores in Poland (including the "click and collect" functionality) (Izakowski, 2017).

Intensive development of the "Smyk" chain and more and more new outlets (in 2017 more than 140 stores), both in Poland and abroad, caused a rapid increase in the volume of goods served by the distribution center. "Smyk" serves clients through three distribution channels: stationary stores in Poland and abroad, franchise partners 
outside Poland and an online store. Each channel has a different dynamics, assortment and service requirements, as well as seasonality conditioned by the climate and culture of a given market.

To ensure the efficiency of customer service processes, "Smyk" uses the logistics service of a specialized operator. The logistics operator provides services in the field of order processing in stores located throughout the country, as well as abroad, logistics services for goods available in "Smyk" stores, warehouse management and customs warehousing. The growing amount of manufactured goods, as well as the need to shorten working time are factors that have a significant impact on logistics processes. The needs and requirements of the market have led to the desire to include automated solutions in the processing of orders, allowing to achieve higher efficiency of processes. To meet the needs of increasing the efficiency of customer service processes, the logistics operator has implemented an automatic sorting machine for order picking for "Smyk". Thanks to this solution, more economical storage space management and better use of resources was achieved. At the same time, the increase in the efficiency of the process and the capacity of the warehouse did not result in the need to expand the warehouse space. Process automation also influenced the work of the selection team. The crew's tasks have become intuitive and the work is more ergonomic (Spedinex, 2017).

Thanks to modern solutions and integration of marketing and logistic processes, the customer has the opportunity to make convenient purchases 24 hours a day, anywhere and the ordered goods can be picked up at your own home, parcel locker or in a selected Smyk stationary store. Thanks to the personal collection of the product in the store, the customer does not have to pay for the shipment, which reduces his purchase cost.

\section{Conclusions}

Nowadays one can observe a tendency to an increasing level of integration of logistics and marketing, which in turn leads to the creation of an integrated concept of logistics and marketing management. For the enterprise it means incorporation of the logistics and marketing strategy into the overall strategy of operation and its application as the basic orientation in value chain management. The main goal of integrated logistics and marketing management is to achieve long-term customer satisfaction, which should at the same time contribute to the generation of longterm profits. As in the case of classic competitive strategies, the aim of this concept is to strengthen the market position and gain a competitive advantage by implementing the set goals and adapting to the changing environment. In achieving these goals, it is necessary to apply specific management instruments including both the classic (marketing mix and logistics mix) as well as modern tools such as: automation of warehouse processes, Electronic Point-of-Sale, effective customer service (ECR), comprehensive quality management (TQM), time-oriented management (TBM) or fast response.

\section{References}

Blaik, P. (2010). Logistyka. Koncepcja zintegrowanego zarządzania. Warszawa: PWE.

Blaik, P. (ed.) (2007). Systemy i procesy zarządzania logistyczno-marketingowego. Aspekt efektywnościowy. Opole: Wydawnictwo Uniwersytetu Opolskiego.

Bujak, A. (2014). The development of the concept of supply chain management as an example of the evolution of Logistics. The Wroclaw School of Banking Research Journal, 15 (1), 133-151.

Dennis, C., Merrilees, W., Fenech, T. (2005). Sale the 7 Cs: teaching/training aid for the (e-)retail mix. International Journal of Retail and Distribution Management, 33 (3), 179-193. 
Fernie, J., Sparks, L. (2004). Retail Logistics: changes and challenges. In: J. Fernie, L. Sparks (eds.), Logistics and retail management: insights into current practice and trends from leading experts (pp. 1-25). London, UK: Kogan Page.

Harrison, A., Hoek, R. Van. (2010). Zarządzanie logistyką. Warszawa: PWE.

Izakowski, Ł. (2017). Smyk usprawnia logistykę w ramach zasady "be multichannel or die" Retrieved from: https://retailnet. pl/2017/05/26/115890-smyk-usprawnia-logistyke-ramach-zasady-be-multichannel-or-die.

Kaźmierczak, M. (2016). Wpływ społecznej odpowiedzialności przedsiębiorstwa na zarządzanie łańcuchem dostaw. Studia Oeconomica Posnaniensia, 4 (12), 95-108.

Lasgaa, M. (2010). How e-retailing can influence your logistics? Groenewout Consultants \& Engineers, February 11, 1-18.

Llamazares, O. (ed.) (2015). Dictionary of international trade Key definitions of 2000 trade terms and acronyms. Global Negotiator.

Pokusa, T. (2006). Logistyczno-marketingowy system tworzenia wartości dla klienta - wybrane elementy. Zeszyty Naukowe. Logistyka i Transport, 3 (2), 51-62.

Pokusa, T. (2007). Logistyka i marketing jako dualna koncepcja zintegrowanego zarządzania przedsiębiorstwem. Problemy Profesjologii, 2, 41-59.

Smyk (2018). Retrieved from: www.smykgroup.com/pl.

Spedinex (2017). Jak usprawnić dostawy do sieci handlowych - Smyk i Spedimex postawili na automatyzację - case study. Retrieved from: http://www.pracujwlogistyce.pl/poradnikexperta-artykuly/20-poradnik-eksperta/5707-jak-usprawnic-dostawy-do-siecihandlowych-smyk-i-spedimex-postawili-na-automatyzacje-case-study.

Topolsek, T., Borut, J., Cvahte, T. (2016). Increasing competitiveness with intercompany integration of Logistics and marketing functions. Production, Engineering, Archives, 10 (1), 29-32.

Wang, K., Wang, Y., Yao, J. (2005). A Comparative Study on Marketing Mix Models for Digital Products. In: X. Deng, Y. Ye (eds.), Internet and Network Economics (pp. 660-669). WINE 2005. Lecture Notes in Computer Science, 3828. Berlin, Heidelberg: Springer.

Worobjow, L. (2010). Koncepcja zarządzania logistyczno-marketingowego: uwarunkowania i etapy opracowania. Zeszyty Naukowe Polityki Europejskie, Finanse i Marketing, 3 (52), 243-252.

Zhou, X.J., Zhang, Q.N. (2010). Research on Construction and Generation of Logistics Value Chain. China Business and Market, 24 (4), 26-29.

Cite this article aS: Drobiazgiewicz, J. (2018). Marketing logistics management in e-retail - the essence and selected practical aspects. European Journal of Service Management, 3 (27/2), 149-155. DOI: 10.18276/ejsm.2018.27/2-18. 